cuts of the kind that those supporting the amendment would have resented deeply. And it would have made orderly government in the United States less attainable.

What follows is not political speculation (of which there is ample in the US press, notably on the theme of how the chances of the next round of presidential candidates will have been affected by the Senate's vote), but a reflection on public budgets generally. It starts from the view that the US federal budget (now, in round numbers, $\$ 200$ billion a year) is indeed too large, certainly in the present modest economic recovery, and that there are gloomy signs that the deficit, institutionalized by President Ronald Reagan, has become chronic. Why else was it so resistant to reduction during the seemingly prosperous late-1980s? The weakness of the US dollar in the past few weeks is partly a consequence of that, now that Japanese institutions and persons are no longer keeping their savings in the United States.

But the US budget a constitutional amendment would have balanced by law is, despite its size, only the tip of an iceberg. A large part of the US government's financial activity is not covered by the budget proper, but by semiautonomous agencies spending funds borrowed from the financial markets and operated in such a way that only deficits appear as costs in the budget that must be financed by federal taxes. From mortgages for affordable housing to many of the loan schemes by which students survive through college courses (not to mention the rescue of the Savings and Loan banks a decade ago), off-budget financing is well tried and widely practised.

The promise of the Balanced Budget Amendment is potentially hollow because the limits of off-budget financing have not been thoroughly explored. Take, for example, federal spending on research, which is discretionary in the sense that no law compels the US government to spend money in this way, but which is a public good that the government needs to support and from which innovation and improved health can reliably be expected to flow. So why not transfer all these activities to a new public corporation (shades of the Galvin report on the US national laboratories, see Nature 373, 463-464; 1995) that would finance them with borrowed funds and would eventually repay the money either from the sale of patents or by means of a levy on the ultimate beneficiaries? It is, of course, a bad idea, but one that future governments caught by a Balanced Budget Amendment might well embrace.

That underlines a more serious difficulty - the distinction between public investment and public spending generally in all public budgets (not only that of the United States). There are many circumstances in which a new road or harbour, or the support of students in higher education, can be reckoned as an ultimately productive tangible investment. Even allowing for the frailty of governments in deciding which investments are worthwhile, there is a case for treating such expenditure differently from what are called, in the United States, 'entitlements'. Technically, the former deserve protection; politically, the shoe is on the other foot. And that is the crux of the budget problem in the United States: the federal budget will not be balanced painlessly, but only by transferring the burden either to state governments or to taxpayers in general. The project for a constitutional amendment has been a way of avoiding that truth.

The other flaw in the whole enterprise is that, in appropriate circumstances, there is a need for governments to run a deficit. Keynes may not now be a congressional idol, but his arithmetic is impeccable. And there is no question that a government stuck in a recession when its rivals are not had better be ready to print a stack of currency notes, whatever the consequences. To deny a government that opportunity is to rob it of competence. That is what would have happened if the amendment had passed last week.

\section{Too-modest ambitions}

The British government should not be content that $\mathbf{3 0}$ per cent of young people enter higher education.

THE British government has created another muddle for itself on participation in higher education. Last week, the higher education funding councils that channel public funds to universities and colleges made public a near-freeze in what they have to spend on the grounds that the proportions of young people going on to higher education have reached 30 per cent, which is the government's ambition. Ironically, it later emerged that the numbers of mature students now following courses at tertiary institutions, which are recorded separately, has greatly increased, so the participation rate substantially exceeds the magic 30 per cent.

There are two things to say about these developments. First, it is a creditable achievement that Britain has been able so to enlarge the proportions of the population in higher education, which have almost doubled in 15 years or thereabouts. The good news is that, in the past few years, there have been welcome signs that the expansion has been sustained by demand, the wish of students to win a higher or professional education. The decision five years ago to designate the old polytechnics as universities (much derided, but not by this journal, at the time) also appears to have had a beneficial influence. The bad news is that British academics remain more badly paid than those elsewhere, and that many institutions have never had the resources to conduct their academic affairs with style.

The second truth about last week's paradox is that the supposition that a participation rate of 30 per cent is a sensible target for British higher education. For one thing, the number is less than the participation rate in Japan (which hovers around 50 per cent). It is also less than current practice in France, where roughly 40 per cent of young people find their way into higher education. Why should Britain be so different, and so much less ambitious? Especially when it is now clear that the poverty of Britain's economic performance since the Second World War is largely attributable to chronic shortages of sophisticated skill, and not only in fields in which technical qualifications are necessary. The way in which mature students are flocking into British institutions is a sign that they, at least, appreciate the need. 